\title{
Delicate Souls between the Veil and the Habit: Images of Galician Ukrainian Women from 1890 to 1950
}

\author{
Roman Holyk \\ Ivan Kryp"iakevych Institute of Ukrainian Studies (Lviv), National Academy of Sciences of \\ Ukraine
}

\begin{abstract}
This article explores the changing image of women in the social discourse and literary texts of Galicia during the late nineteenth and first half of the twentieth century. It begins with an analysis of memoirs by Ukrainian women and, in a few instances, of men. The study highlights the writings and readings of Galician women. It examines the cultural world of women who came primarily from the intelligentsia, clerical families or burgher society and were teachers, writers, and civic activists. It delineates the problems Ukrainian women encountered in choosing a life and the options society offered them: raising a family, entering a convent, or remaining single (unmarried). A separate section, based on Galician sources of the first half of the twentieth century, looks at women stigmatics and the social attitudes toward them. The article compares the image of the urban woman from the intelligentsia with that of peasant women in a modernizing society. On the basis of women's biographies, autobiographies, literary works devoted to women's themes, as well as the "women's" press, the author attempts to reconstruct the various images of women in the Galician milieu before the Second World War.
\end{abstract}

Keywords: Ukrainian Women, Feminism, Galicia, Writing, Reading, Stereotypes

In memory of Marta Danylewycz and her family

$\mathrm{T}$ hree decades ago feminist critics had pointed out that the history of European literature and culture was described overwhelmingly from a masculine, patriarchal perspective (Gilbert and Gubar 47). This view applies especially to the history of Ukrainian literature and culture: it has basically been a history about male authors.

In his recent and innovative monograph Larry Wolff drew attention to the mechanisms that formed Galicia as an Austrian province and Galician identity. Studies of gender and regional identity have also reified the image of the Galician Ukrainian woman in nineteenth- and twentieth-century social and literary discourses. Those who have focused on this subject include the Ukrainian-American historian Martha Bohachevsky-Chomiak and the Ukrainian scholars Oksana Malanchuk-Rybak, Myroslava Diadiuk, 
Oksana Kis, Ivanna Cherchovych, Nataliia Dmytryshyn, and Marta Hosovs'ka, among others.

This article is not about women's social roles or their fate; it focuses on texts-written either by or about women. It is an attempt to delineate the phenomenology and mental archaeology of women's writings, and the social imagination and stereotypes of women during the late nineteenth and first half of the twentieth century. The key concept is literary and public discourse as represented in a collection of texts, together with their contexts, meanings and connotations.

The starting point of this study are a number of core ideas formulated by Marta Danylewycz, a Canadian social historian (unfortunately little known in Ukraine) who researched Canada's (and more specifically Quebec's) nineteenth- and early twentieth-century Francophone and Anglophone communities (Danylewycz 1981; Danylewycz, Light, and Prentice 1983; Danylewycz and Prentice 1984 and 1986; Danylewycz 1987 and 1988). Her work will echo through three central themes of this article: (1) the Galician public's perception of the female teacher and her place in society; (2) the two options society offered Galician women: marriage or taking the veil; (3) the views men held about women (and women about men), examined as elements of social discourse. I will try to examine aspects of Galician society that Danylewycz and her coauthors did not touch upon, namely, the intellectual life of Galician women, the social attitudes and views of the nineteenth and early twentieth centuries that regulated women's behaviour and were revealed in literary and memoir texts. Attention will also be devoted to images of the soul and body, i.e., of the psychological and corporeal, of emotions and feelings as projected in texts. Naturally, the spectrum of identified issues is quite broad; therefore, I will outline only the general contours, subordinating my narrative to the texts, adopting their images and categories.

Marta Danylewycz's scholarly texts are an example of how the generation of Galician immigrants and refugees, born after the Second World War, were assimilated into West European and, later, North American cultural milieus. ${ }^{1}$ There are, however, other types of texts, those

${ }_{1}^{1}$ Marta Danylewycz was born in 1947 in a displaced-persons camp in Germany. In 1949 she immigrated with her refugee parents to the USA and settled in Cleveland, Ohio, where she grew up in a Ukrainian émigré community focussed on preserving a Ukrainian national and Ukrainian Greek Catholic identity (she graduated from a Catholic high school for girls). In 1970 Danylewycz came to Canada to pursue graduate studies. Her biographers mention that she described the UkrainianAmerican community in which she grew up as conservative and quite closed. That is 
written by women of the older generation in Danylewycz's family, as well as by their female contemporaries. These can serve both as examples of a certain kind of women's memoir writing and as specimens of the ideas and stereotypes that prevailed among Galician Ukrainian (i.e., Ruthenian) women in the nineteenth and twentieth centuries.

These autobiographies generally fit into a scheme proposed by Malgorzata Czermińska (2000)—“confession," "testimony," "challenge" but require some additional explanation. Indeed, most of the women's autobiographies considered here are, more or less, profound "confessions." Nonetheless, the "confessions" discussed here do not exclude the notion of "testimonies," and actually overlap with them. ${ }^{2}$ Moreover, each of these women's texts is a discrete, individual "confession" within a specific context. Thus, instead of using Czermińska's "autobiographical triangle," we turn to Ogden and Richards's "semiotic triangle," one corner of which is formed by words, and the other two by words and concepts (ideas) (Ogden and Richards 11). Such a model is relative-and even metaphorical. But it does allow one to present various aspects of the image of women in Galician memoirs: their chronological and structural-semantic dimensions, as well as their social and ideological context.

why Danylewycz tried to modernize and move away from views (including those about gender) that prevailed in the émigré milieu and to enter into a multicultural world and examine the history of the Other from the perspective of the Other. The communities of Catholic nuns in Quebec, the social status and careers of Canadian female teachers, and the general trends in gender relations in Canada during the late nineteenth and early twentieth centuries became the primary subjects of her historical research. In time, the ideas Danylewycz propounded in her works until her tragic death in 1985 became an integral part of the scholarly paradigm in her field (Trimingham 80-81). Her colleagues have deemed her a strong, almost mythical personality and one of the leading Canadian specialists in feminist studies during the early 1980s (Hamelin; Trofimenkoff). Together with Danylewycz's husband Marko Bojcun, his sisters, and Marta's friends they established the Marta Danylewycz Memorial Fund at the Canadian Research Institute for the Advancement of Women with the primary objective of continuing, promoting, and supporting work in women's history from a feminist perspective.

2 In certain cases, we can even speak of a "confessional testimony," where introspection is accompanied by the fixing of historical events. After all, everyone who "confesses" in their autobiography has witnessed events and the social phenomena among which they live. 


\section{THINGS: THE GALICIAN WoMAN IN QUOTIDIAN FocUS}

I will begin by looking at the narratives of those Galician women who tried to record only facts or events, to which they added relatively expanded commentaries. Their texts are stylistically and figuratively simple, rarely "decorated" with quotations or dialogues, without detailed descriptions of locales, landscapes, and so on. They are quite laconic and follow the rules of ordinary conversation rather than principles of literary composition. Each of these autobiographies was supposed to show the trajectory of a woman's life as she climbed the social ladder. In the texts under analysis one finds several variations of such strategies. They offer portraits of female characters that correspond to the social realities of day.

The first trajectory is that from a priest's daughter to a teacher and/or to priest's wife. Thus, Marta Danylewycz's grandmother, Olena Danylevych (née Kunins'ka, 1876-1959) wrote her brief memoirs in the late 1950s to remind her descendants about her "life's sufferings" up to the year 1900 (Holyk 2011, 250-51). ${ }^{3}$ Her text has a noticeable religious tinge. It begins with the phrase "V im"ia Bozhe" (In God's name), and thereafter uses proverbs such as "Nad syrotoiu - Hospod' Boh z kalytoiu” (The Lord God stands with a money purse over the orphan) to elaborate the narrative.

Olena Danylevych created for herself a multidimensional image. One shows her as a representative of a family with an old but impoverished clerical lineage. Another draws a picture of a girl raised (with many siblings) in a parish priest's family in the Hutsul region; she becomes an orphan at an early age. Danylevych describes her childhood years as a chain of privations. At the same time, she describes her female relatives and separates them into two categories. ${ }^{4}$

Danylevych's education in a girl's school in Chernivtsi was special. She admits, "The worst thing ... was making a stocking, because part of the curriculum was [knitting] a stocking. More than once I wept bitterly when the stitches unravelled (iak popuskaly ochka)" (Holyk 2011, 250).

3 This study also provides other versions of classification and interpretation of Galician women's autobiographies written during the late nineteenth and the first half of the twentieth century.

${ }^{4}$ In the first category Danylevych includes women in whose presence she felt "good" (like her grandmother): these, were capable housewives knowledgeable in running a household and childrearing. In the second group were women seen as "bad": women who did not care about raising their children properly or running a household, those who pursued a social life filled "with diversions" (iz zabavamy) and dined in restaurants (Holyk 2011, 250). 
Danylevych portrays her own youth emotionally, mentioning her brief teaching experience at a gymnasium in a multiethnic (Ukrainian-PolishJewish) milieu after completing eight years of studies in a gymnasium. Generally, the story of her childhood and adolescence is a story of emotional upheavals ranging from joy to sorrow. Her narrative abruptly ends at the turn of the twentieth century. It is an example of laconic, aphoristic women's writing.

The brief memoir of Danylevych's daughter, Mariia Savchak (née Danylevych, 1905-94) was set against a broader and more emotional background (Holyk 2011, 252-57). Apparently, the narrator kept in mind her mother's narrative. She describes in detail her childhood experiences, her years of study in a gymnasium and teacher's college in the 1920s and 1930s, teaching in Galician villages, and her life during both World Wars. Finally, she discussed her teacher's job in the Lemko region in the postwar period when she found herself living between official (Polish) and unofficial (anti-Soviet, underground) powers. Savchak's text creates a rather typical picture of a Galician female teacher from a priest's family. She, like her husband, often had to change her place of work. This author, who was relatively independent, yet bound to her husband and children, repeatedly stresses her key role in decision-making during extreme wartime situations. In her fragmentary discourse, two emotional currents dominate: fear, emotional upheaval, and anxiety on the one hand; happiness and pride in her achievements on the other. By and large, Savchak depicts the women and men in her life in neutral terms. Only when their deeds did not fit within the moral framework of her milieu does she condemn them. ${ }^{5}$ The texts of Danylevych and her daughter reflect everyday life in terms of commonsense thinking. Their memoirs have no pretence to being literature, nor did the authors aspire to the status of writers.

The autobiography of Nataliia Isaievych (née Chaban, 1904-82), the mother of the prominent Ukrainian historian Yaroslav Isaievych (1936-

5 Savchak considered one priest, whose father was a precentor, to be eccentric because he did not treat his children equally: "He had daughters whom he did not send to school, saying 'let them marry peasants,' but he taught his son" (Holyk 2011, 253). The fate of a teacher whom Savchak knew attracted her attention when the teacher married her late sister's husband; she did not have a happy marriage, yet after her husband died she threw herself under a train (Holyk 2011, 254). Both examples correspond to the model of bourgeois morality, class consciousness, notions of proper and improper deeds, and also to novels for teenage girls that were written during the late nineteenth and first half of the twentieth century (with their themes of suicide). 
2010) is, in a way, similar to the aforementioned examples. Her reminiscences depict the path of a girl from a semi-rural, suburban family to a teaching position (Isaievych 883-96). Isaievych's personality did not develop in the milieu of priests and their wives, but among small merchants and suburbanites. She focuses not only on the history of her family, but also on public and intellectual life in Galicia. Besides the careers of her parents, Isaievych relates the development of Ukrainian associations and ethnic relations in Stryi and Peremyshl. She pays considerable attention to the community of female students at the Ukrainian teacher's college in Peremyshl, the student boarding school run by the Ukrainian Basilian Sisters, and her relationships with the teaching nuns and friends.

Isaievych depicts this society as closed but pleasant; usually the girls were not allowed to leave the residence, and only on Sunday were they permitted to go to church in pairs. Her text also notes the students' response to the literary texts they read. ${ }^{6}$ However, in addition to her interest in reading, Isaievych's memoir also shows signs of interest in the body, i.e., fashion. ${ }^{7}$ Isaievych lived simultaneously in two worlds: in the realm of ideas and intellectual discussions, and in the material world of things and daily life. Both had an impact on her personality (i.e., "soul"), and thus on her writing.

6 The first recollections of reading in Isaievych's memoirs is associated with her younger sister Iuliia, who learned how to read early and nearly by herself: "I remember how she asked [our] eldest [sister] Helia to teach her how to read the alphabet, [both] Ukrainian and Latin. Sister Helia explained how words are made up of letters, [our] older brother reinforced her knowledge, showed her the German script, and she, not being even five years old, [was able] read in three languages" (Isaievych 887). In Isaievych's memoir her comprehension of literary texts is linked with her school years. Significantly, her attempt at literary analysis of a text is associated with Ol'ha Kobylians'ka's early twentieth-century emblematic images of women. Isaievych particularly emphasizes that even as a schoolgirl she could competently decode the character of Kobylians'ka's novel Tsarivna (The Princess): "She [the Princess] widely read philosophical literature, [and] criticized the narrowminded Romanian intelligentsia... She was a princess in spirit!" (Isaievych 894).

${ }^{7}$ For example, Isaievych mentions what clothing the artist Olena Kul'chyts'ka wore: It was an expression of the Austrian Secession-inspired fascination with folk motifs. "She clothed herself with artistic taste. In summer she wore a skirt and jacket sewn from gray, homespun cloth, [and] on her shoulder a bag [decorated] with folk ornament[s]. She also inculcated in her female students a respect for folk dress" (Isaievych 895). 
A different level of female writing in Galicia is represented by memoirs whose authors tried to "earn" the right to be professional writers alongside men. In these texts the autobiographical "confession" often becomes a "tale" with all the attributes of a creative work of the late nineteenth and early twentieth century. These works contain a plot, characters, monologues and dialogues, a detailed description of the heroines' internal experiences, descriptions of nature as reflections of the female soul, and so on.

We see this type (or prototype) of Galician Ukrainian female writing in the works of Uliana Kravchenko (pen name of Julia Schneider, 1860-1947). In her poetry she paints an image of the suffering woman, creating an antithesis between the ideal "woman-princess" and the real "womancaptive," who is confined to the "golden cage" of social conventions. ${ }^{8}$ At the same time, in Zapysky uchytel'ky (Notes of a Teacher) Kravchenko develops the image of an intellectual girl who ends up in a provincial town (Bibrka) and adjacent villages, struggling against her environment on behalf of a single goal: the edification of her pupils. It is not surprising therefore that women's literacy and reading become one of the leading themes in her discourse.

In Zapysky... the author identifies a paradigm of the good reading material, designed to educate "tireless female workers in the spirit of truth and love” (Kravchenko 2010, 30). Kravchenko's ideals were subordinated to the idea of progress (popular in the 1890s), to realism, and to classical literature. ${ }^{9}$ The various reading materials mentioned in Zapysky... correspond to two types of women: the first has a healthy body and is not subject to the dictates of fashion. Thanks to her "hygienic life," she does not need cosmetics. The second woman has an anaemic, skinny body; she

\footnotetext{
8 “Жінко - невольнице звичаїв темна, / Приймаєш болі та всі труди земні. / В нетямі серед сліз, невіжі хмар / Мов той Атлант, підносиш свій тягар /(...) / Життя без просвітку, і біль, і труди, / А що для тебе скарбом в чорну хвилю буде?" (Trydtsiat' ukrains'kykh poetes 92).

9 Her heroine, schooled on high-school readings of Homer, Dante, Shakespeare, Cervantes, and Goethe, ponders the ideas of Charles Darwin and Kant's Prolegomena and encourages others to read Flaubert, Balzac, and Zola. The girl is attracted to books containing "psychology and ethnography" that awaken "joyful energy." The female teacher favours Carl Linné's strict scientific text much more than Balzac's chaotic epic. To these ideals Uliana Kravchenko juxtaposed "bad" (nedobra) reading materials for women: Émile Gaboriau's sensational detective fiction, Georg F. Born's (pen name of K. G. Füllborn) romance novels, handbooks about proper behaviour, and pamphlets with formulaic conversational clichés.
} 
chases after fashions, both in clothing and literature. In trying to persuade one of her pupils, who is captivated by sensational publications, Kravchenko's heroine compares fashionable books with "bad feed [kormom] for the body and the spirit," and even with "poisonous flowers, black flowers-a carnivorous genus (rid m"iasozhernykh) that grows in swamps-that's what all your novels with [their] flashy adventure plots are" (Kravchenko 2010, 59). The latter sentence is not unexpected: Kravchenko was after all both a writer and a botany teacher.

As time passed, however, the literary component became dominant in Uliana Kravchenko's texts, and she began introducing herself, as a "woman of the book" for whom cultivating the spirit was central. It is no accident that she compares reading with hard agricultural work (e.g., plowing the soil) and sees her own texts as a battle between emotion and intellect. "My book," she writes, reflects "the pathos of the struggle of... intellect (positivism) and faith (feeling-intuition)" (Kravchenko 2010, 171). Alternately, the struggle is between the female and male soul: "My book is a princely gift of his soul ... and the flowers of my heart" (Kravchenko 2010, 171). However, just as important for Kravchenko was the image of the male as "friend" and "brother," as the "Berkut" (eagle) and the "Boian" (bard) from whom she seeks support. The latter reference was, of course, to Ivan Franko (Kravchenko 1996, 18).

Of particular importance to Kravchenko was the image or concept of the female soul, which she described as "full of intuition, inspiration, mercysympathy" (Kravchenko 2010, 136). She tried to represent her biography as the "imprint," "reflection," "semblance of the soul," picturing herself as "beauty's servant in the depth of [my] soul" (Kravchenko 2010, 110).

Also meaningful for this writer was the issue of her outward appearance, fashion and clothing. She did not like ordinary, unfashionable dress; nevertheless, she found festive attire forced, oppressive, yet something one had to accept. ${ }^{10}$ Her texts contain images of particularly romantic attire that is donned by her imaginary spiritual alter ego, which is garbed, for example, "in white linen clothing, in a mistletoe wreath" (Kravchenko 2010, 113). In short, women in Uliana Kravchenko's texts are as much reality as they are a utopian ideal.

10 "When not necessarily in a happy mood, I put on a black lace dress adorned generously with bunches of pale-pink acacia blossoms; on [my] neck [I place] strands of small pearls, and weave pearls of beads into [my] hair. Pearls-next to flowers-are the only accessories I like. In addition, [I put on] patent leather shoes, gloves, [and] a fan. Taken together, all of this reflects in the mirror as a somewhat mournful but very elegant outfit" (Kravchenko 2010, 45-46). 
Ol'ha Duchymins'ka (née Reshetylovych, 1883-1988) (Duchymins'ka 152-218) offers another example. In her narrative, facts also surrendered to romantic images, and chains of reminiscences take the place of a clear chronology. The central theme again is the career of a female teacher. But her protagonist is inscribed into a specific context: her exemplary elementary schoolteacher aspires to "serve" the people (particularly Ukrainian peasants), to lead them out of the darkness of ignorance, to reform their social consciousness, and to improve their material well-being (Varanytsia 361-70).

Duchymins'ka's memoir is a history of how she herself attained selfawareness. It is a tale about the mental evolution of a female Ruthenian inteligent, a woman born into a mixed Polish Russophile family, who nevertheless (under the influence of an unnamed male friend) became a devotee of Ukrainophile ideology. Duchymins'ka's family tree contained a long line of priests, a fact that influenced her life. She was conscious of a "Russophile" childhood in terms of writings, readings, and the Galician orthographic wars. ${ }^{11}$

The writer shows how a "woman-child" grew up to become a schoolteacher. She recounts how her "good father" encouraged her to learn through intensive reading. Knowledge became a distinct alternative to the traditional female dowry. ${ }^{12}$ However, following her father's death, a difficult period ensues "among strangers," when "a young soul" is broken during a period when there was no respect for books or independent thinking (Duchymins'ka 154).13 Radical changes in her worldview are stimulated through a complex mix of readings - both in and outside school. ${ }^{14}$

11 "I came from an idealistic [ideinoho] Russophile home [katsaps'skoho domu]. The words "the people" and "serving" them were bywords in our house... With my teenage [kil'kalitn'oiu] hand I signed a protest against the introduction of phonetics [i.e., phonetic orthography]. And I was very proud I had signed against the 'destruction' of [my] native tongue" (Duchymins'ka 164-65).

12 "Learn, daughter! I want to give you property before I die. You will never be poor. No force will destroy the property I shall give you. As long as you live, you will be rich!... And truly, [my] good father knew how to provide for [vyvinuvaty] his children" (Duchymins'ka 154).

${ }^{13}$ After the death of her parents, the girl lived with relatives who were not fond of reading and did not allow her to express independent views.

14 She reads Taras Shevchenko's Kobzar, Ivan Franko's works, Bohdan Lepkyi's poetry, and Vasyl' Pachovs'kyi's drama "Son litn'oi nochi" [Summer Night's Dream] the writings of Stefan Żeromski, Nietzsche, Ibsen, Plato, Christian authors (St. Augustine) and the new mystics (August Strindberg). But the heroine of her 
Reading led Duchymins'ka to her own personal discourse based on classical Ukrainian prose and poetry. In her memoir she also tried to reconstruct the emancipatory views of her youth: she spoke of marriage as the "great mundaneness" (velyka budenshchyna) that diverts a person from ethical and aesthetic ideals; she referred to "friendship as art" (pryiazn' iak mytstetstvo) and love as a "variant of egoism" (riznovyd egoizmu)."15 In her system, patriotism rises above lyricism, the male cult is rejected fully, and the image of the submissive woman is a synonym for humiliation and underestimation of one's own potential. ${ }^{16}$ In general, Duchymins'ka saw her young self as a girl outside conventional female society; she has nothing in common with those girls who worry about "engagements," "broken engagements" or "unhappy love" (Duchymins'ka 184).

At the same time Duchymins'ka's discourse shows her transition from idealistic feminism to a realistic vision of the intellectual woman and the civic activist with her own family. Here the images of exemplary Galician and Bukovynian women played a role: Ol'ha Kobylians'ka (1863-1942), Konstantyna Malyts'ka (1872-1947), Sofiia Okunevs'ka-Morachevs'ka (1865-1926), and Olimpiia Levyts'ka (1851-1915) were the ideals of her youth. ${ }^{17}$

Still another focus in the memoir of this Galician female teacher and writer is fashion: in the late nineteenth and early twentieth centuries it was not only an element that emphasized one's beauty, but also an attribute of one's national identity. For Duchymins'ka the eclectic folk dress was an ethnic marker. ${ }^{18}$ On the other hand, the then fashionable European style of

memoirs treats belle lettres with caution, because they "take time away" and can "undermine faith and love in the world."

15 She admits, "I kept track of life in the village, of the life of the peasant woman. I was a feminist, but one without slogans, without preparation. I had just begun getting familiar with Kobylians'ka's works-[and] this made an impact" (Duchymins'ka 163).

16 “They look to see what 'he' will say, how 'he' thinks, whether 'he' likes this. This 'he' in all [grammatical] cases. It's so insulting... Being only an 'appendage' to 'him.' And these were women who worked for themselves!" (Duchymins'ka 177).

17 About Olimpiia Levyts'ka she enthusiastically writes: "The eldest one earnestly cared for the younger children after [their] father's death and, forgetting her [own] 'ego' ... lived for them and the general welfare... Olimpiia knew how to bring peace to everything ... To work for society at large was my ideal, and Olimpiia was [my] model of perfection" (Duchymins'ka, 185).

18 These included: strings of shiny coral beads or gerdany [beaded collars] adorning the neck; long ribbons or gerdany in the hair (fashion also dictated beaded watch chains). Among some Lviv's women Cossack hats, with a lowered bottom part 
women's clothing emphasized the wearer's sophisticated taste. The latter transformed Duchymins'ka's own image in her memoir. ${ }^{19}$ Nonetheless, the concept of the young "vernal soul," inspired by "the people's ideals" dominated her discourse.

\section{IDEAS: THE GALICIAN WOMAN WITHIN SOCIAL AND RELIGIOUS CONFLICTS}

In Structural Anthropology Claude Lévi-Strausse wrote about "interpreting society as a whole in terms of a theory of communication," saying, rather provocatively, that "the rules of kinship and marriage serve to insure the circulation of women between groups, just as economic rules serve to insure the circulation of goods and services, and linguistic rules the circulation of messages" (Lévi-Strausse 83). He had in mind primitive societies, but this unintentionally equated woman with an object of exchange between male communities. In modern Galician society such extremes did not exist, but women nevertheless were also determined by a system of mental binaries, ideological divisions, stereotypes, and prejudices.

On the eve of the twentieth century there appeared a clear distinction between two types of Galician women: the good, gentle, compromising, natural mother who was a model housewife and spouse; and the energetic, "decisive," impulsive, strong woman of action who was reluctant to compromise (Bokhens'ka 30). Some literary texts and memoirs depicted women in the family circle, while others did the opposite, showing them beyond the bounds of the home and private concerns, acting on the stage of Galician social and religious life. These autobiographies and memoirs thus became partial "eyewitness" accounts, reflecting the ideological debates in local communities. Such texts "challenged" the reader's consciousness, not in a literary sense (as described by Czermińska) but in the social. They were supposed to transform how men imagined social life and the role of women

(shchenevmerlychky), were popular. Other items included: the embroidered blouse; skirt; a women's woven woolen belt (kraika) for the dress; a wraparound skirt [zapaska] decorated with embroidery; a traditional wool coat [zhupan], and so on. The folkish nature of the clothing was additionally emphasized by the cut, the material from which it was made, the density of the decoration, and so on. In addition, the clothing had to match the style of the woman's hairdo (e.g., the kolistse, a "peasant" type of coiffure).

19 "Grecian gloves" (rukavy hrets'ki), a coiffure à la Empress Elisabeth (known in the vernacular as a 'stork's nest'). But how good [it felt to be] ... in this dress! Merry [and] festive" (Duchymins'ka 175). 
in it. In particular, this pertained to Galician feminist ideals, even though this feminism had various origins and forms.

The autobiography and literary discourse of one of the first Galician feminists, Nataliia Kobryns'ka (1855-1920), is the history of a woman who came from an educated clerical milieu and long relied on the help of likeminded men. One source of her feminism, aside from ideology, was her living conditions, namely, her husband's transfer from village to city, which also freed Kobryns'ka from physical labour. ${ }^{20}$ In addition, Kobryns'ka resolutely connected Ukrainian literary discourse and "Cossack" mythology with women and their emancipation movement in Galicia. ${ }^{21}$ At the same time she juxtaposed the images of men and women sharply: "The more a man values himself in accordance with cultural dictates, the more a woman drops to the value of money" (Kobryns'ka 315). Therefore there was a need for a "gender revolution" within traditional Galician society.

Another ideal woman for many intellectually inclined Galician women was Konstantyna Malyts'ka (pseud.: Vira Lebedova, 1872-1947). In her autobiographical piece "Z dytiachykh lit" (Excerpts from my Childhood Years) she recalls hearing recitations of Taras Shevchenko's poems at a public evening dedicated to him; in "Na fil'mi spomyniv" (Memories at the Movies) she describes how she promoted the Ukrainian women's movement in Bukovyna together with Ol'ha Zhurakivs'ka and Yevheniia Yaroshyns'ka and espoused views about women's emancipation that were more radical than Kobylians'ka's; and in "Na khvyliakh svitovoi viiny" (On the Waves of World War) she writes about being one of thousands who were evacuated to Siberia during the Russian army's retreat from Galicia in 1915 (Vykhovnytsia pokolin' 46-81).

These writings formed an image of Malyts'ka as an "unswerving educator of generations," a "tireless builder of our life," a lonely, ascetic feminist, and a teacher with a somewhat peculiar approach to her pupils. Ivanna Petriv recalls Malyts'ka's "chimerical smile, [which] was her entire

20 "The reduced scale of a woman's responsibility for the household in the city attracted my attention to the unproductiveness of women's work and the wasting of time on trivialities. So I began thinking about the reform of women's responsibility for the household and even introducing certain small changes in my own house. These changes greatly surprised and angered my servants, but my husband and Sofiia Okunevs'ka strongly supported all of them" (Kobryns'ka 318-19).

21 "When increasingly more rebellious elements rose up, the feelings of the Galician woman also revolted-her Cossack blood began to boil, and she desired liberty not only for the [common] people, but also for her own female will... We are evolving on the field of general progress, whose measure always was literature and the woman" (Kobryns'ka 327-28). 
[display of] tenderness toward us. Not having her own family and children, she did not give us [any] maternal warmth outside [the family], but we felt good in her presence" (Vykhovnytsia pokolin' 42). ${ }^{22}$ At the same time, the style and rhetoric of Vira Lebedova's poetry (e.g., "Mali heroi" and "Chysten'kyi i Iurza Murza") present a different image of Malyts'ka: as a person who was close to children and understood their thinking.

The memoirs of Stryi resident Osypa Bobykevych-Nyzhankivs'ka (1869-1952) present yet another image of the active woman. Although she was raised in a Polish-speaking family, she chose to become a "Ruthenian" and later the wife of Father Oleksa Bobykevych. Osypa BobykevychNyzhankivs'ka remained in the shadow of her husband's social activism. But she gradually also became a civic figure and travelled actively. After her husband's death, together with her daughter Nina (Neonila) she shared the difficult fate of a priest's widow, taking responsibility for all of the family's problems and finances. Her memoirs are an older woman's dense text "addressed to [her] grandchildren, great-grandchildren, and [persons] close to [her] soul" (Bobykevych-Nyzhankivs'ka 152).

The "priest's wife in charge of the household" and the "schoolteacher/writer" were two popular models of femininity-a consequence of the limited social prospects educated Galician women had (Cherchovych 503-16). A casual analysis might suggest that they represented polar opposites: conventional, traditional femininity (i.e., the priest's wife) and visions of the Nietzschean woman (Kobylians'ka's "superwoman-princess"). However, in reality all of these models were part of a single system of artistic images and imaginings about women's social status and their professional opportunities.

Some of these models underwent a certain evolution. Already at the turn of the twentieth century the image of the active woman-a woman who abandons the management of the household in the name of social activism or a career as a writer, artist, or even an educator-encountered misgivings from families of priests and the intelligentsia in Galicia. Women's political activity was even perceived as something dangerous. The Russophile activist Ol'ha Hrabar, as one example, and the Ukrainian Socialist radical Anna Pavlyk, as another, both served as instances of such danger. For a variety of reasons, the two women fell into the category of "politicals," therefore viewed as delinquent women and subjected to ostracism.

\footnotetext{
${ }^{22}$ Malyts'ka's closely associates herself with reading in her memoir. As a teacher she willingly lent her pupils books from her own library, but upon their return she sternly examined them about the books' contents.
} 
The image of the "delinquent women" (Hosovs'ka 75) also appeared in belles-lettres. She was rarely exonerated by social, economic, or moral conditions. ${ }^{23}$ Yet another stereotype that was popular in the late nineteenth century was the image of the femme fatale who brought about a man's death or ruin. ${ }^{24}$ In the first half of the twentieth century, cinema provided the image of the vamp, a female figure with strong but "dark" passions (Bokhens'kyi 42). The profession of female author was associated with a liberated, bohemian lifestyle, but also elicited wariness. Any creative woman (writer, painter, singer, and even elementary school teacher) could be accused of neglecting her family, her household, and child-rearing responsibilities. For example, Solomiia Krushelnyts'ka (1872-1952), who came from a clerical milieu, was viewed in two ways: as a prominent singer who brought fame to Galicia, and as a woman who renounced the traditional way of life for the stage (Solomiia Krushel'nyts'ka). However, in her case, as in the attitude toward the artist Olena Kul'chyts'ka (18771967), there also appeared the motif of self-sacrifice on behalf of art, the community, and the nation. ${ }^{25}$ Asceticism and solitude served as a "justification" for their type of life, which was generally frowned upon in other instances.

A case in point might be Galician Ukrainian society's non-acceptance of Ivan Franko's wife, Ol'ha Khoruzhyns'ka (1864-1941). Women regarded her manner of dress too simple and even deliberately domestic, and her behaviour a violation of the rules of good taste and damaging to her husband's status. During the first few decades of the twentieth century Khoruzhyns'ka was regarded as an example of yet another tragic figure familiar to readers of nineteenth- and early twentieth-century literature: the woman who goes insane. ${ }^{26}$ Galician writer and Bukovynian priest's wife

23 The heroine of Franko's short novel, Dlia domashn'oho vohnyshcha (For the Family Hearth) can serve as an example. She is shown organizing a network of brothels in Lviv (cf. Hosovs'ka 71-80). In contrast, Leonid Kunyts'kyi (in his funeral sermons) paints an image of a female schoolteacher with tuberculosis who sacrifices herself for her pupils by living in damp basements (Kunyts'kyi 83-84). Teodor Bohachevs'kyi (also in his sermons) proposed the image of an "exemplary schoolteacher" who combines civic and Christian virtues-and called society to respect her (Bohachevs'kyi 260).

${ }^{24}$ Such, in effect, are the characters Regina, from Ivan Franko's novel Lel' i Polel' (cf. Muranets'), and Anna in Franko's drama Ukradene shchastia.

25 In her poetry Malyts'ka depicted the image of a hapless woman (“Другим доля стелить квіти / Мені терновії віти; / Другим медом тече струя / Мені пливуть їдь, отруя" (Trydtsiat' 158).

${ }^{26}$ Ol'ha Khoruzhyns'ka suffered from hereditary mental illness. 
Klymentyna Popovych-Boiars'ka (1863-1945) also shared this fate. Her texts contained the image of the despotic man (symbolized through "ivy") who destroys a woman ("the rose") by depriving her of her life force (Trydtsiat' 99). She, like Khoruzhyns'ka and Uliana Kravchenko, was later also viewed as the "woman [or love] of Ivan Franko" (Hrytsak 305-32). ${ }^{27}$

After the First World War the situation changed. At that time, the image of the female warrior and heroine became especially pertinent, leading, for example, to the cult of Olena Stepaniv-Dashkevych ("Stepanivna") (18921963), Sofiia Halechko (1891-1918) as well as other women who had fought in the ranks of the Ukrainian Sich Riflemen and Ukrainian Galician Army. They were depicted simultaneously as fearless soldiers and intelligent, delicate, yet physically strong young women who were capable of disrupting a battle and leading soldiers in an attack. This gave birth to the legend of the Battle of Mount Makivka and a song about the heroine, "Stepanivna." Also included in the ranks of such women is Ol'ha Levyts'kaBasarab (1889-1924) of the underground Ukrainian Military Organization. After her tragic death in a Lviv prison she was honoured as a revolutionary martyr and a symbol of the Galician Ukrainian struggle against the interwar Polish state.

By this time, attitudes toward so-called "women's" and "non-women's" professions had changed. For example, at the end of the nineteenth century only Sofiia Okunevs'ka-Morachevs'ka (1865-1926) had dared to pursue a career as a physician. But during and after the First World War a number of female Ukrainian doctors appeared in Galicia: Dariia Lezhohubs'ka-Chubata (Chubatova) (1890-1934), Teodoziia Tuna-Nadraga (Nadragova) (18931976), Olena Polotniuk-Hrobel'na (1897-1944), Yaroslava Rudnyts'kaKryshtal's'ka (1898-1966), and, Sofiia Parfanovych-Volchuk (1898-1968) (Pundii 124, 162, 175-76, 189, 205-207, 231-232). This changed the image of the medical practitioner in society: next to the familiar male physician, the female doctor appeared. In addition, in the case of Teodoziia TunaNadraga (1893-1976), the image of the civilian female physician was combined with the image of the female Ukrainian Galician Army medic. As for Sofiia Parfanovych (1898-1968), this doctor was also active in the

27 Franko actively supported the notion of women's social liberation and spoke out against "women's captivity" in Ukrainian folk and elite culture. Out of principle, as he later admitted, Franko married a woman from eastern Ukraine because she held "progressive" views and because this marriage was to symbolize the unity of Ukrainian lands (Hrytsak 327). However, in the opinion of Galician society Franko's ideal partner would have been the priest's daughter Ol'ha Roshkevych-Ozarkevych (1857-1953)—but they never married (Hrytsak 329). 
feminist movement and appeared as the author of a popular book about women's hygiene, as well as of stories and novels.

Attitudes toward female writers and female journalists also changed. One example of this is the popular response to the stories of Iryna Vil'de (pen name of Daryna Makohon-Polotniuk, 1907-82), with their dominant theme of liberating women ("pinned butterflies") from social stereotypes. The priest's daughter Dariia Yaroslavs'ka (pen name of Dariia Stoliarchuk, née Borodaikevych, 1905-82) also developed this theme in her prose. After being deceived by men, the main heroine of her early novel Polyn' pid nohamy (Wormwood under Foot, 1938) chooses to follow her own path and establishes a small enterprise (Yaroslavs'ka, 1938). Women started being perceived not only as schoolteachers, but also as pedagogues, school inspectors, and school guardians and patrons. (Two married couplesIvanna and Illia Kokorudza and Ivanna and Denys Petriv-played particularly important roles in this regard.) At the same time, the 1920s and 1930s became a time when ideas about femininity and women's literary discourse became more polarized.28 One example of the ideological differences that arose was the conflict between women who considered themselves Ukrainian and those who were Russophiles and referred to themselves as "Galician Russian ladies" [halyts'ko-russkymy zhenshchynamy (damamy)] (Veshniia vody 63-71). ${ }^{29}$

These changes in the image of women are corroborated in memoirs written by people born in interwar Galicia. Larysa Krushel'nyts'ka (born in 1928), a representative of a prominent intelligentsia family, who became an archeologist, recalls that she spent her childhood reading books, talking about them, and interacting with extraordinary women in Lviv's ethnic Ukrainian community. This included her mother, the pianist Halyna Levyts'ka (1901-49), physicians Volodymyra Kryshelnyts'ka (1903-37) and Sofiia Parfanovych, musicologist Zofia Lissa (1908-80), artist and

${ }^{28}$ For example, fans of the historical novels of Katria Hrynevych (Banakh, 18751947) considered her to be the leading female Galician Ukrainian writer, rejecting Iryna Vil'de, whom they accused of pursuing fashionable liberation themes (Hrynevych, 58).

29 This was also reflected in what authors were read and in what language: Shevchenko, Franko, Ukrainka, and Kobylians'ka were read by circles of Ukrainian women; Pushkin, Lermontov, and Tolstoy by Russophile women. For example, Ol'ha Duchymins'ka wrote that she was brought up on reading Russian literature, whereas the texts of Shevchenko had to be read secretly at night (Duchymins'ka 164-165). 
scholar Sofiia Krasyns'ka-Val'nyts'ka (1896-64), travel writer Sofiia Yablons'ka-Uden (1907-71), and others (Krushel'nyts'ka 56-57).

Most of these figures represented the new, strong, and dynamic women who took on functions that were still reserved only for men at the beginning of the twentieth century. In the process, Volodymyra Krushel'nyts'ka created a tripartite image for herself: a Ukrainian-speaking girl raised on contemporary European culture (this was before she emigrated with her parents to Kharkiv in Soviet Ukraine); a Russianspeaking child who was placed in a Soviet boarding institution after her family was repressed in 1934; and, finally, a girl who was re-educated as a Galician Ukrainian after she returned to Lviv in 1936. These transformations reflected the political and cultural atmosphere of that time, particularly the Sovietization process of Galician women, which became a reality in 1939.

A former resident of Lviv, the postwar émigré poet Lida Palii, recalls the interwar years through a prism of blurred, swiftly flowing images. In her memoirs childhood is portrayed on two planes. One is the world of mature women, who attend balls and "uninteresting" fashion salons organized by the Union of Ukrainian Women (Soiuz ukrainok), as well as vacations at the beach and in the mountains. The other is a girl's world; she goes to school, reads the magazine Svit dytyny (Child's World), writes her first verses, and feels "funny" when teachers start addressing her by the second person plural Vy or as pani- "madam" (Palii 30). ${ }^{30}$

The memoirs and speeches of the promoter of the Ukrainian feminist movement in interwar Galicia, member of the Polish Sejm, Milena Rudnyts'ka (1892-1975), present her as a women who, because of her mixed Ukrainian-Jewish origin and unorthodox views, was forced to struggle against the traditional communities of both men and women and to uproot the prevailing view that women play only a subordinate role in society. Rudnyts'ka attacked the married/unmarried designation of women, criticizing such terms as metsenasova, radnykova, sluzhbovychka (respectively, "wife of a benefactor," "wife of councillor," "wife of a civil servant"), pani (Mrs.), and pannochka (Young Miss), emphasizing instead women's human essence (Rudnyts'ka 249). As a public figure, she also

30 Palii recollects the schooling and private education of girls as an education, on one hand, about the body and graceful movements; on the other, it was about the formation of national consciousness, through, among other things, meetings with prominent figures of the women's movement, particularly Sofiia Rusova, unofficial commemorations of the passing of Ol'ha Basarab, and so on. 
constituted a relatively new vision of women as political activists and parliamentarians. ${ }^{31}$

The paradigm of feminist modernization during the 1920s and 1930s in Galicia was reflected in the women's periodicals Nova khata (The New Home, published in Lviv) and Zhinocha dolia (Women's Fate, published in Kolomyia). Their female authors tried to speak to their readers in the new language of mobility and activism, stressing the importance of sports, travel, rational eating, hygiene, new fashion styles, new furnishings for the urban woman's private space, and so on. But they did not reject the traditional image of woman: they called upon women in Lviv's intelligentsia milieu to wear homespun clothing, to decorate their kitchens on peasant patterns, and to maintain folk traditions as markers of their national identity in what was then a predominantly Polish-speaking city (Holyk 2014).

The public discourse was full of relative dichotomies. They existed in the consciousness of women themselves, who frequently assimilated them from an external source-the discourse of men. One of these dichotomies was the juxtaposition between the religious and secular woman, and the urban and rural. There are few women's texts, particularly memoirs, which are devoted wholly to religiosity. Among them is the literary autobiography of Mariia Kuz'movych-Holovins'ka (1904-86). It portrays a young Christian girl who witnesses historical and family events, while remaining aloof from dangerous (i.e., seductive) literature-thanks to her peculiar and constant reverence for the Zarvanytsia icon (Kuz'movych-Holovins'ka 5). ${ }^{32}$ Images of peasant women appeared often in the discourse of Galicia's female intelligentsia-but they are mostly objects, not subjects, of the narrative. ${ }^{33}$

31 The texts of Milena Rudnyts'ka's brother, literary critic Mykhailo Rudnyts'kyi, can be seen as a dissonant postscript to her own views. On one hand, he supported the literature of women's emancipation, particularly Iryna Vil'de's works, and was generally interested in the image of the new woman in world discourse (see his preface to the Ukrainian translation of Charlotte Brontë's Jane Eyre published in 1939 under the title Idealistka [The Idealistic Woman]). However, he sometimes expressed scepticism about feminist ideas and ironically characterized both conservative women and women who were overly supportive of the ideas of modernization (Rudnyts'kyi 5).

${ }^{32}$ This is a miraculous icon of Our Lady of Zarvanytsia, actually located in a village in the Terebovlia region of Ternopil oblast in the west of Ukraine.

33 Peasant women in some cases enter into brief dialogue with urban women and even offer them advice. But they appeared mostly as persons with a different psychology that had to be modernized and changed. Feminists tried to present them as "younger sisters" who per force did not know the city and its culture and 
The male-female dichotomy was another fundamental binary within which the literary imagination operated. The traditional female discourse either neutralized it or demonstrated that the domination of man over woman was the norm; feminist discourse, on the other hand, called this norm an anomaly and pushed for gender equality and women's autonomy, and, in some cases, even posited women's moral superiority. Male discourse, especially in memoirs, minimized the role of women to a certain extent. In the autobiographies of male Galician activists women figured primarily in the context of marriage, in specific episodes of family life, or when they participated in the public arena (Cherchovych 2014, 212-13).

Another image of women is found in Father Havryil Kostel'nyk's texts about the stigmatics Nastia Voloshyn (later Sister Mariam, 1911-94), Evstakhiia Bokhniak (1903-71), and Hanna Hruba (1913-83). Father Kostel'nyk based his writings on his faith in spiritism and stigmata, and relied on the texts of nuns who served as intermediaries tasked with recording the words and deeds of stigmatics (Pislantsi z taiemnoho svitu). These nuns were peasant women, not particularly literate, who had been allowed to read only the Holy Bible and newspapers, serving as channels between the spiritual world (angels), Christ, and the common people. They presented their visionary texts not as their own words but as the utterances of higher forces, whose instruments (dushechky) they purportedly were.

Nastia Voloshyn and Evstakhiia Bokhniak convinced others that they had truly received mystical powers and had the ability to be present simultaneously in several places, assume another person's ailments, and miraculously restore crosses and icons in various parts of Galicia. Those who believed the stigmatics (e.g., Father Kostel'nyk and Konstantyn Chekhovych) tried to be expert guarantors of the veracity of their words, particularly in male company. Other specialists (typically men and mostly Polish theologians and physicians) tried to prove that the revelations of female Ukrainian stigmatics and their bloody stigmata were only a symptom of heightened psychic sensitivity, spiritual illness, or skilful simulation and charlatanry. As a result, the bodies, souls, and texts of the stigmatics became, metaphorically speaking, a subject of heated theological and even political discussion.

therefore only occupied a social niche as servants. In some texts, however, peasant women appear on the margins as background to the narrative. As a rule, these are just "some kind" of peasants talking about their personal matters. In Dariia Iaroslavs'ka's novel, Polyn pid nohamy ("The Wormwood under Foot"), the main heroine listens to a conversation of some rural women "about hemp" (Iaroslavs'ka 50). These peasant women belong to a parallel, non-urban world. 
The hagiographic work by the Belgian Redemptorist, Father Joseph Schrijvers, about Sister Varvara (Kateryna Shapka, 1896-1942), founder of the Galician Ukrainian Sisters of St. Joseph (Skhreyvers 2012), occupies a different niche. It is a French-language retelling of a Ukrainian-language autobiography that Father Schrijvers, Sister Varvara's confessor, commanded her to write. Hers is the account of a peasant girl whose supernatural visions convince her to renounce married life and the "world" in general. She undergoes a number of ordeals: family conflicts; encirclement by men with "evil intentions," who try to seduce her; dissatisfaction with other nuns who consider this peasant girl undeserving of a life devoted to prayer; and, finally, performance of physically hard (men's) labour that destroys her body, covers it in sores, and makes it coarse. Even though Father Schrijvers's interpretation softens somewhat Sister Varvara's original text, it is an uncommon autobiography of a peasant woman who is transformed into a saintly founder or reformer of a new monastic community. The range of what she read was quite narrow: primarily prayer books, the lives of saints, and the Bible. This is reflected in the narrative fabric of her story. At the same time it is proof of her strong and extraordinary character.

Sister Varvara's text leads to a broader issue: the general trends in the formation and development of women's writing in Galicia in the late nineteenth and the first half of the twentieth century. This writing travelled along the same path as the image of women in society's consciousness and in the artistic imagination; in short, from the traditional stereotype of a housewife who cooks well, dresses elegantly, behaves properly, and raises children in a religious spirit to a well-read and educated professional and civic activist. This is how the image of the feminist came about: a woman who wants to change society, its notions, and to articulate them in a new manner. ${ }^{34}$

34 The Galician Ukrainian economic and political diaspora, particularly in the United States and Canada, played a role here. Already the first generations of female immigrants who first ended up "between shores" and later "under foreign stars," like the heroines of Dariia Iaroslavs'ka's tales and novels (Iaroslavs'ka 1971, Iaroslavs'ka 1953), were forced to discard their customary ideas about how a woman must look and behave. The postwar wave of Ukrainian refugees and immigrants and their offspring, whom Marta Danylewycz represents, went even further-they merged with a different, new world of women. However, the women who remained in Soviet-occupied Western Ukraine were forced to change their discourse and way of thinking under the influence of the Communist canon and to become typical female citizens of the Ukrainian SSR. 


\section{CONCLUSION}

The Galician Ukrainian woman of the nineteenth and the first half of the twentieth century remained at the crossroads of three options: (1) the veil, i.e., marriage, family, and raising children; (2) the nun's habit, i.e., ascetic life in a convent; or (3) living as a lonely civic activist, desiring to change everything around her. Some advised women to become wives devoted to their children, the household, and religion. Others recommended that a woman take vows in order to save her soul and pray for the world's salvation. Still others saw her as a freethinking, well-read intellectual who creates her own texts, discourse, and lifestyle. There is no doubt that women's writings in Galicia grew and developed quite actively. How much these writings (and therefore the culture of Galician women) truly broke away from men's writing, and how much it repeated the latter, is a topic for further research. In the end, this article-the history of female discourse written by a male-is as modern as it is traditional.

\section{Works Cited}

Bobykevych-Nyzhankivs'ka, Osypa. "Spomyny z moikh rokiv.” Oleksa Bobykevych, Tvory. Lviv: Kameniar, 2000. 152-81. Print.

Bohachevs'ka, Marta. Bilym po bilomu: Zhinky u hromads'komu zhytti Ukraïny, 18841939. Kyiv: Lybid', 1995. Print.

Bohachevsky-Chomiak, Martha. Feminists despite Themselves: Women in Ukrainian Community Life, 1884-1939. Edmonton: Canadian Institute of Ukrainian Studies, University of Alberta, 1988. Print.

Bohachevs'kyi, Teodor. Pokhoronni propovidy. Zhovkva: Drukarnia oo. Vasyliian, 1932. Print.

Bokhens'ka, Ievheniia. Tvory. Lviv: Kameniar, 2002. Print.

Bokhens'kyi, Iaroslav. Sribni tiny. (Pro fil'move mystetstvo). Lviv: Dobra Knyzhka, 1927. Print.

Cherchovych, Ivanna. "Dzherela do vyvchennia povsiakdennia ukrainok v Halychyni zlamu XIX-XX st." Visnyk Lvivs'koho universytetu. Seriia: knyhoznavsto, bibliotekoznavstvo ta informatsiini tekhnolohii. 8 (2014): 207-219. Print.

Cherchovych, Ivanna. "Zhinka v rodyni hreko-katolyts'koho sviashchennyka u Halychyni druhoi polovyny XIX - pochatku XIX st." Istoriia relihii v Ukraini 1 (2012): 503-16. Print.

Czermińska, Małgorzata. Autobiograficzny trójkąt: Świadectwo, wyznanie i wyzwanie. Cracow: Universitas, 2000. Print. 
Danylewycz, Marta. "Changing Relationships, Nuns and Feminists in Montreal, 1890-1925." Histoire sociale - Social History 14.28 (November 1981): 413-34. Print.

---. Profession: religieuse. Un choix pour les Québécoises, 1840-1920. Texte mis au point et présenté par Paul-André Linteau, Alison Prentice et William Westfall. Tran. de Gérard Boulad. Montreal: Boréal, 1988. Print.

---. Taking the Veil: An Alternative to Marriage, Motherhood and Spinsterhood in Quebec, 1840-1920. Toronto: McClelland and Stewart, 1987. Print.

---. and Alison Prentice. "Teachers, Gender, and Bureaucratizing School Systems in Nineteenth Century Montreal and Toronto." History of Education Quarterly 24.1 (Spring 1984): 75-100. Print.

---. and Alison Prentice. "Teachers' Work: Changing Patterns and Perceptions in the Emerging School Systems of Nineteenth- and Early Twentieth-Century Central Canada." Labour/Le travail 17 (Spring 1986): 59-80. Print.

---. Beth Light, and Alison Prentice. "The Evolution of a Sexual Division of Labour in Teaching: A Nineteenth-Century Ontario and Quebec Case Study." Histoire sociale - Social History 16.31 (May 1983): 81-109. Print.

Dmytryshyn, Nataliia. "Zhinka u hreko-katolyts'kii sviashchenychii sim'i u Halychyni: biohrafiia na tli epokhy." Research Center. "Borderland Society: Past and Present." Web. 31 May 2015. <www.timeandspace.lviv.ua/ index.php?module=academic\&section $=$ research\&id $=9>$.

Duchymins'ka, Ol'ha. "Vesniani dni." Sumnyi Khrystos. Lviv: Kameniar, 1992. 152218. Print.

Diadiuk, Myroslava. Ukrains'kyi zhinochyi rukh u mizhviyennii Halychyni: mizh hendernoiu identychnistiu ta natsional'noiu zaanhazhovanistiu. Lviv: Astroliabiia, 2011. Print.

Gilbert, Sandra M., and Susan Gubar. The Madwoman in the Attic: The Woman Writer and the Nineteenth-Century Literary Imagination. New Haven: Yale University Press, 1984. Print.

Hamelin, Monique. "Une femme marquée par la tragedie: Marta Danylewycz." L'autre parole. Web. 31 May 2015. <http://www.lautreparole.org/articles/ 1233>.

Holyk, Roman. "Istorii chotyr'okh dush: obraz halyts'koï vchytel'ky i stereotypy gendernoho dyskursu kintsia XIX - pershoi polovyny XX stolittia." Ukrains'ka mova $v$ Halychyni: istorychnyi vymir. Ed. Yaroslav Isaievych, Michael Moser, and Nataliia Khobzei. Lviv: Instytut ukrainoznavstva im. I. Kryp"iakevycha NAN Ukraïny, 2011. 204-57. Print.

---. "Mizh emansypatsiieiu i narodnoiu tradytsiieiu: zhinka, stereotypy ta povsiakdenne zhyttia na storinkakh l'vivs'koï periodyky 20-30 rr. XX st.” Narodoznavchi zoshyty 1 (2014): 29-37. Web. 31 May 2015. <http:// nz.ethnology.lviv.ua/archiv/2014-1/6.pdf>. 
Hosovs'ka, Marta. "Feministychni modeli prozy Ivana Franka: do problemy naukovoho i khudozhn'oho myslennia." Paradyhma: Zbirnyk naukovykh prats' 4 (2009). Lviv: Instytut ukrainoznavstva im. I. Kryp"iakevycha NAN Ukraïny. 7180. Web. 31 May 2015. <http://www.inst-ukr.lviv.ua/files/paradygma/71-80gm.pdf>.

Hrynevych, Jaroslav. Katria Hrynevycheva. Biohrafichnyj narys. Toronto: Homin Ukrainy, 1968. Print.

Hrytsak, Yaroslav. Prorok u svoii vitchyzni: Franko ta ioho spil'nota (1856-1886). Kyiv: Krytyka, 2006. Print.

Iaroslavs'ka, Dariia. Polyn pid nohamy. Lviv: Dilo, 1938. Print.

---. Pid chuzhi zori: Roman. Toronto: Dobra knyzhka, 1971. Print.

---. Pomizh berehamy: Povist'. Philadelphia: Kyiv, 1953. Print.

Isaievych (Chabanivna), Natalia. "Stryi i Peremyshl': Kartky spomyniv." Confraternitas: Iuvileinyi zbirnyk na poshanu Yaroslava Isaievycha. Ukraina: kul'turna spadshchyna, natsional'na svidomist', derzhavnist': Zbirnyk naukovykh prats'. Lviv: Instytut ukraïnoznavstva im. I. Kryp'iakevycha NAN Ukraïny. 15 (2006-2007). 883-96. Web. 31 May 2015. <http://www.inst-ukr.lviv.ua/files/23/ 840SpohadyMamy.pdf>.

Jack, Christine Trimingham. "What's in a Veil? Discourses Informing a Study of Lay Sisters." Change: Transformation in Education 4.1 (May 2001): 76-90. Web. 31 May 2015. <http://ses.library.usyd.edu.au//bitstream/2123/4440/1/ Vol4No1Article6.pdf $>$.

Kis', Oksana. Zhinka v tradytsiinii ukrains'kii kul'turi (druha polovyna XIX - pochatok XX st. Lviv: Instytut narodoznavstva NAN Ukraïny, 2008. Print.

Kobryns'ka, Nataliia. Vybrani tvory. Kyiv: Dnipro, 1980. Print.

Kravchenko, Uliana. Pam'iati druha: Virshi v prozi, statti, spohady, lysty. Lviv: Kameniar, 1996. Print.

---. Zapysky uchytel'ky. Lviv: Apriori, 2010. Print.

Krushel'nyts'ka, Larysa. Rubaly lis... (Spohady halychanky). Lviv: L'vivs'ka naukova biblioteka im. V. Stefanyka NAN Ukrainy, 2001. Print.

Kunyts'kyi, Leontii. Na vichnyi shliakh: Pokhoronni propovidy. Lviv: Drukarnia Stavropihiial'noho instytutu, 1926. Print.

Kuz'movych-Holovins'ka, Mariia. Portret: Avtobiohrafiia. Toronto: Dobra knyzhka, 1978. Print.

Lévi-Strauss, Claude. Structural Anthropology. Trans. Claire Jacobson and Brooke Grundfest Schoepf. New York: Basic Books, 1963. Print.

Malanchuk-Rybak, Oksana. Ideolohiia i suspil'na praktyka zhinochoho rukhu na zakhidnoukrains'kykh zemliakh XIX - pershoï tretyny XX st.: typolohiia ta ievropeys'kyi kul'turno-istorychnyi kontekst. Chernivtsi: Knyhy-XXI, 2006. Print.

Muranets', Tetiana. "Portret fatal'noi zhinky u prozi Ivana Franka." Visnyk L'vivs'koho universytetu: Seriia filolohichna 58 (2013): 82-97. Web. 31 May 
2015.<http://lnu.edu.ua/faculty/Philol/www/visnyk/58_2013/58_2013_08m uranets.pdf>.

Ogden, C. K., and I. A. Richards. The Meaning of Meaning: A Study of the Influence of Language upon Thought and of the Science of Symbolism. Orlando, FL: Harcourt Brace Jovanovich, 1989. Print.

Palii, Lida. Dytynstvo, zametene chasom. Kyiv: Yaroslaviv val, 2006. Print.

Pislantsi z taiemnoho svitu: Evstakhiia Bokhniak. Zbirnyk materialiv. Vol. 1. Lviv: Papuha, 2009. Print.

Pislantsi z taiemnoho svitu: Anasastasiia Voloshyn. Zbirnyk materialiv. Vol. 2. Lviv: Papuha, 2009. Print.

“Propam'iatnyi fond Marty Danylevych." Svoboda 25 July 1987: 3. Print.

Pundii, Pavlo. Ukrains'ki likari: Biobibliohrafichnyi dovidnyk. Vol. 1. Lviv and Chicago: Naukove tovarystvo im. T. Shevchenka u L'vovi, 1994. Print.

Rudnyts'ka, Milena. Statti, lysty, dokumenty. Lviv: Litopys, 1998. Print.

Rudnyts'kyi, Mykhailo. "Shevchenko pro krasuni." Nova Khata. 6 (June 1935): 5. Print.

Seniv, Ivan. Tvorchist' Oleny L'vivny Kul'chyts'koi. Kyiv: Vydavnytstvo Akademii nauk Ukrains'koï RSR, 1961. Print.

Solomiia Krushel'nyts'ka: Spohady, materialy, lystuvannia. 2 vols. Ed. M. I. Holovashchenko. Kyiv: Muzychna Ukraina, 1978-79. Print.

Skhreivers, Iosyf [Schrijvers, Joseph]. Chudesne zhyttia Sestry Varvary Kateryny Shapky, Heneral'noi nastoiatel'ky sester Iosyfitok, 1896-1942. Trans. Fr. Bohdan Kurylas. Lviv: Zhromadzhennia sester sv. Iosyfa OPDM, 2012. Print.

Trofimenkoff, Susan Mann. "Marta Danylewycz, 1947-1985." Histoire sociale - Social History 18.35 (May 1985): 221-22. Web. 31 May 2015. <http://hssh.journals.yorku.ca/index.php/hssh/article/viewFile/37605/34115>.

Trydtsiat' ukrains'kykh poetes: Antolohiia. Kyiv: Radians'kyi pys'mennyk, 1968. Print. Varanytsia, Anna. "Narodna vchytel'ka v Halychyni druhoi polovyny XIX - pochatku $\mathrm{XX}$ st. (do pytannia pro emansypatsiiu zhinky)." Halychyna: Naukovyi $i$ kul'turno-prosvitnii kraieznavchyi chasopys (Ivan-Frankivsk) 22-23 (2013): 361-70. Web. 31 May 2015. <http://www.irbis-nbuv.gov.ua/cgibin/irbis_nbuv/cgiirbis_64.exe?Z21ID $=\& I 21 D B N=U J R N \& P 21 D B N=U J R N \& S 21 \mathrm{~S}$ $\mathrm{TN}=1 \& \mathrm{~S} 21 \mathrm{REF}=10 \& \mathrm{~S} 21 \mathrm{FMT}=$ njuu_all $\& \mathrm{C} 21 \mathrm{COM}=\mathrm{S} \& \mathrm{~S} 21 \mathrm{CNR}=20 \& \mathrm{~S} 21 \mathrm{P} 01=0 \&$ $\mathrm{S} 21 \mathrm{P} 02=0 \& \mathrm{~S} 21 \mathrm{COLORTERMS}=0 \& \mathrm{~S} 21 \mathrm{P} 03=\mathrm{I}=\& \mathrm{~S} 21 \mathrm{STR}=\% \mathrm{D} 0 \% 9669453 / 2013 / 2$ $2-23>$.

Vykhovnytsia pokolin' Konstantyna Malyts'ka: Hromads'ka diiachka, pedahoh $i$ pys'mennytsia. Toronto: Drukarnia “Kyïv," 1965. Print.

Veshniia vody: Sbornik statei posviashchennykh shestidesiatiletiiu Obshchestva russkikh studentov "Drug" ("Akademicheskii kruzhok"), 1871-1931. Lviv: Obshchestvo russkikh studentov "Drug," 1932. Print.

Wolff, Larry. The Idea of Galicia: History and Fantasy in Habsburg Political Culture. Stanford: Stanford University Press, 2010. Print. 